\title{
Frontal View Face Detection on Color Image Processing using Template Matching Method
}

\author{
Nur Agung Budi Kusuma \\ Informatics Department \\ Universitas Nasional \\ Sawo Manila Street, Pasar \\ Minggu, Jakarta
}

\author{
Ina Agustina \\ Informatics Department \\ Universitas Nasional \\ Sawo Manila Street, \\ Pasar Minggu, Jakarta
}

\author{
Fauziah Nasir \\ Informatics Department \\ Universitas Nasional \\ Sawo Manila Street, \\ Pasar Minggu, Jakarta
}

\begin{abstract}
In The determination of face area has got high development over the last decade and its application is in all fields, such as in an investigation. The scientific research about the determination of face area has been conducted until now. Although it is very easy to be identified by human eyes, but the automation of computer processing needs various image processing techniques. The method used in this study is template matching. Template matching is one of techniques in image processing which function is to fit each part of image and the image which is a template. This study aims to make a program to detect human face of image result which will be fitted to the original one using template this study, the writer uses a software, namely Open Computer Vision 3 (OpenCV3) to process an image and uses Python 3 (programming language). The result of this study is from 30 color images data processed, the application is able to identify 30 images and the level of accuracy is $100 \%$.
\end{abstract}

\section{General Terms}

Face Detection using Template Matching Method.

\section{Keywords}

Face model, face area, template matching.

\section{INTRODUCTION}

The determination of human face area has delivered an application which seems difficult at first, such as video sequences coding, video conference, and face identification. The most important one in determining face area is producing an image which can be used to code, manipulate, model, identify a pattern, and look for an object. The method in determining the face area is changing the color of image become greyish. Then the frontal view face detection is located in that area which will indicate whether that is the face area which will also produce coordinate of the face area. By this coordinate, a rectangle will be drawn on the original image which is the final result of this study. Many researchers have implemented template matching for many things in social life.

One of researches which has ever conducted is the implementation of template matching method to detect vehicles. The introcuction of license plate number on this application uses template matching method. An input image containing a template is compared to the template on the database. Template is usually located in the center of image which is compared and a number of points which are suitable to the template is counted. This step is repeated to all input images which will be compared. The biggest appropriate point which is between input image and template indicates that the template is an image template which is the most suitable to the input image. This application has been tested by using 34 data and the accuracy level is $100 \%$ of 34 data tested. [1].

The next study is the use of template matching to determine human face area in the color image based on the skin color. In the first step, the color image is changed to greyish image. The image has greyish value indicating a pixel which is probably skin area. Then the skin probability image is floated using adaptive floating method. The floating image is a binary image which consists of skin area and non skin area. Afterward it determines whether the segmented skin area is face area or not. The result of this study indicates that the use of information about skin color and template matching method can detect human face in color image. The level of face area introcuction which the level of success is $100 \%$ is $75 \%$ [2].

The next study is the system of face introduction using template matching method. In that study, it willdelevop a system which will separate face image to image component. Then it is extracted to eye feature and the face limit in the single image captured from front side. Among components, the distances are measured. Then it is combined to the other features to create semantic face. By face detection phase which is based on the type of skin color, face area normalization and eye feature extraction, the distance of each feature can be determined [3].

The next study is the application of template matching method to clarify fingerprint developed by converting grayscale image to biner image, thinning to get one pixel fingerprint, doing image line segmentation (divided into four directions), resizingimage line to be $32 \times 32$ pixel and clarifying the fingerprint into six levels of fingerprint [4].

The next study is the use of template matching method to identify a disorder on the PCB. In this study, it will create an application which simulate verification process between master PCB and input PCB which belongs to disorder, this application is able to detect the location of disorder occurred by marking the PCB area having disorder [5].

The next study is the application of image processing in introducing the pattern ofNgalagena letter using Matlab. This study uses quantitative method because it is an experiment in introducing the pattern of Ngalagena letter and the final result is the calculation of test percentage on the application created. Based on the result of test conducted to 3 types of image, the black digital character image with template gets $88 \%$ on the test. The black digital character image which is different from the template gets $60,87 \%$ on the test. The black handwriting character image gets $32 \%$ on the test [6].

Based on the background, the writer would like to create a program which title is frontal view face detection on color 
image processing using template matching method. This system will produce sub image containing face which has succeed to be detected by using template matching method on the face.

In order to relevant to the problem, this study has problem limitation. Firstly, theintroductiom of face area conducted is frontal and there area two face images in the color image. Secondly, the type of image used is color image. Lastly, the simulation in this study uses OPENCV3 and PYTHON3.

\section{METHODOLOGY}

\subsection{Recearch Design}

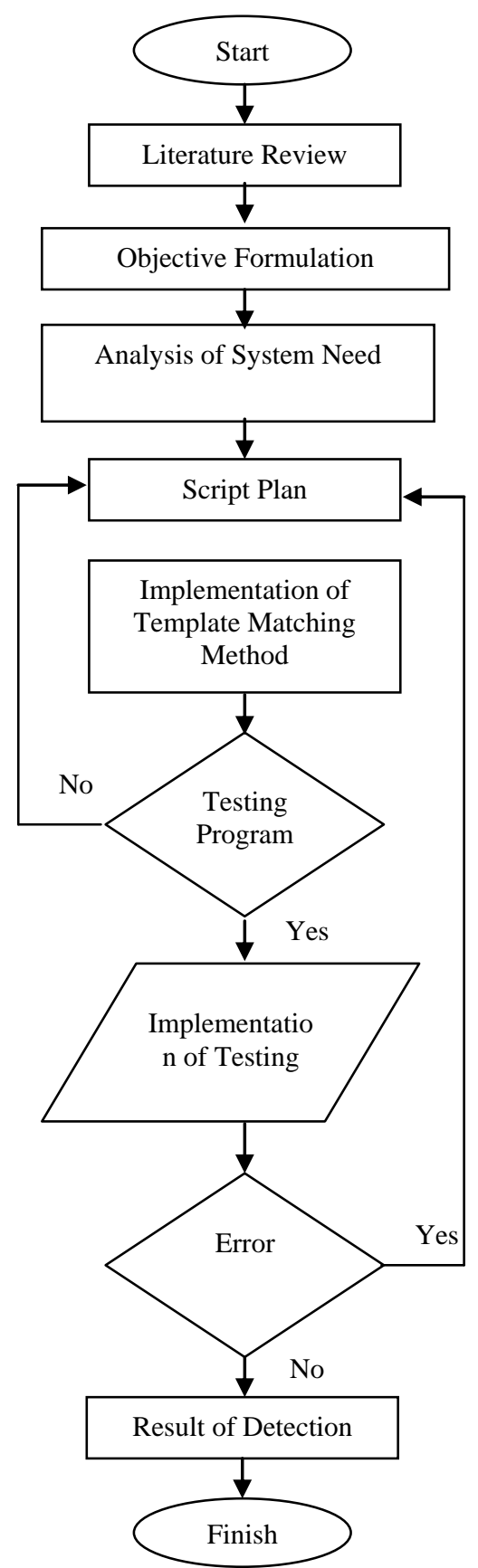

Fig 1. Research Design Flowchart

It explains about the research design flowchart.The research design flowchart starts with literature review phase and formulate the objective to solve the problem. The next phase is analyzing the system need. Then it enters to the script design phase and implements template matching method in the program created. The last phase conducted after creating the prohram is implementation and test. The first implementation is conducted in the template matching method. If it succeeds, it will enter to the testing program, but if it fails, it will return to the script design phase. The test is conducted when the implementation of template matching method runs well. In implementation and testing phase, it is conducted for many times until the best result is gained. If there is error, it will return to script design phase. The process is done, if the best result has gained.

\subsection{OpenCV3 dan Python3}

Open Computer Vision (OpenCV) is a library open source which the special aim is to process an image. It aims to make computer have the same visual processing ability as human.OpenCVhas provided many basic computer vision algorithms, such as template matching.

Python is a free software having many packckages and tools. The start setup is ready to use and has belonged to Python distribution.

\subsection{Template Matching}

Template matching is one of technique in image processing used to fit each part of image toward the image which becomes a template.

Template matching method is one of popular methods used when getting problem in adjusting the pattern in the image processing. Many reearchershave implemented template matching for many things in social life.

In the previous study it is said that in template matching, frontal face pattern is determined manually by a function. In designing this program, the result of image will be detected on the face area to fit to the face part using template matching method.

\section{RESULT AND DISCUSSION}

This section shows the result of application and test of this research approach which consists of test of face image detection. The performance of this detection is to search for the suitable image which is the result of crop on face will be detected with original image which will create detection on that face. If the face is detected it will be marked with square mark on the faces which are the same. In this study, the writer uses some hardwares and softwares which is mentioned below.

Table 1 The specification of hardware

\begin{tabular}{|c|c|}
\hline Device & Specification \\
\hline Processor & Intel Dual-Core N3050 \\
\hline VGA & Intel (R) HD Graphics \\
\hline Harddisk & $500 \mathrm{~GB}$ \\
\hline RAM & $2 \mathrm{~GB}$ \\
\hline
\end{tabular}


Table 2 The specification of software

\begin{tabular}{|c|}
\hline Software \\
\hline OpenCV3 \\
\hline Python3 \\
\hline PyCharm \\
\hline
\end{tabular}

The first step in using this application is choosing the button on the prime image. The image which I choose is an image having many faces and one of them will be cropped and saved in the folder. The image ehich is the result of crop will be used in the second step. Image 2 is GUI system mentioned below.

\begin{tabular}{|l|}
\hline Image matching Program \\
\hline Input The Main Image \\
input the image you want to match \\
\\
\hline
\end{tabular}

Fig. 2 GUI

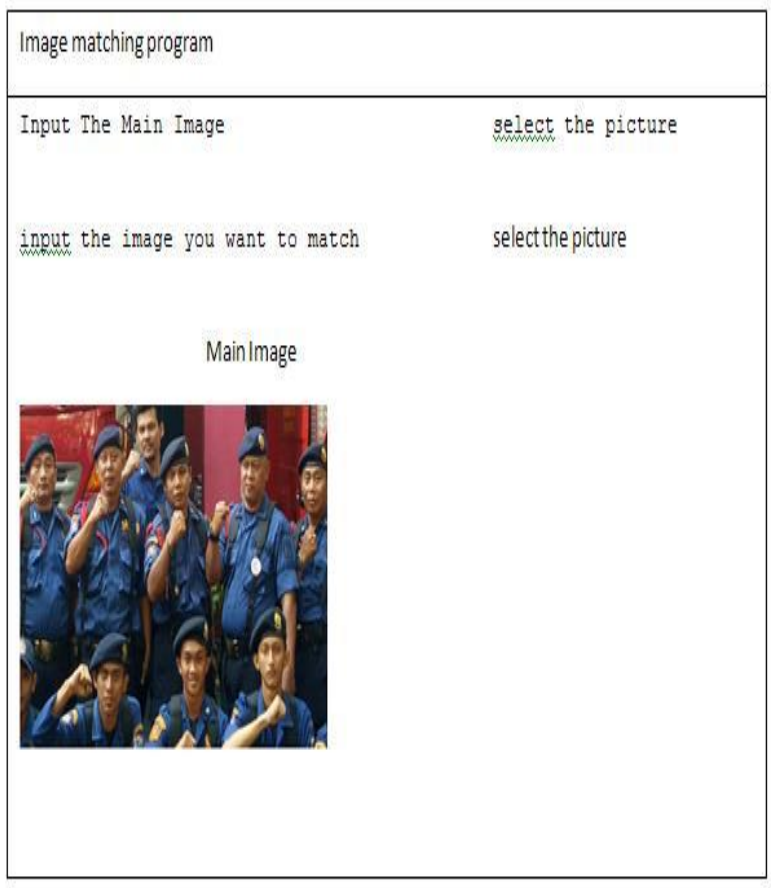

Fig. 3 Choose the prime image

After choosing an image which will be detected, it will appear in GUI.

The second step is choosing the button "choose the image: to choose images which will be fitted and have been saved in folder. After choosing it, the system will be produced output automatically. It is a mark on the face which succeed to be detected by the system.

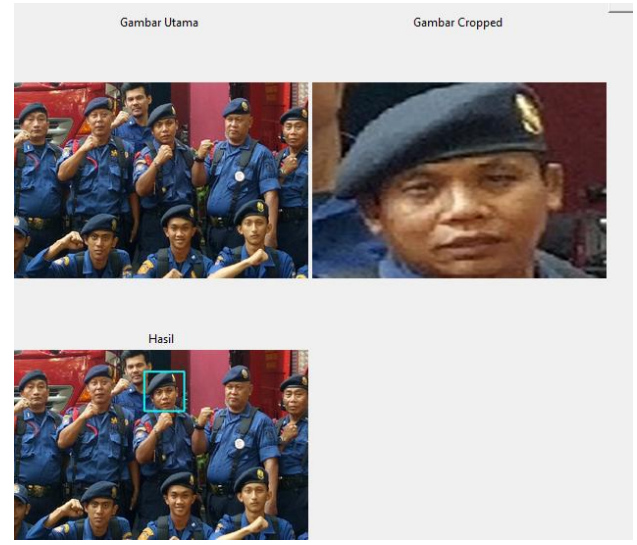

Fig. 4. The result of face detection

The result of the image is an image which is tested after passing by thresholding processing. Thresholding is managing the sensitivity of image adjustment. The image succeeds to be detected well. the result of the image which has been detected will be saved automatically in folder created.

The prime image input to the application will be processed to be grayscale or greyish to ease the system in processing the image.

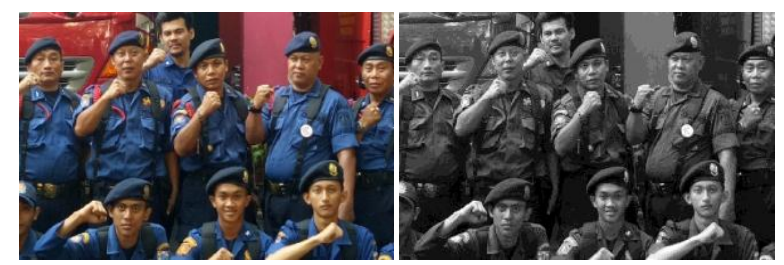

Fig. 5The prime image converted to the greyish one

Then the template image or original image is cropped and input to the application. Then it is processed to be grayscale or greyish to ease the system to determine the length and width on the template image used.
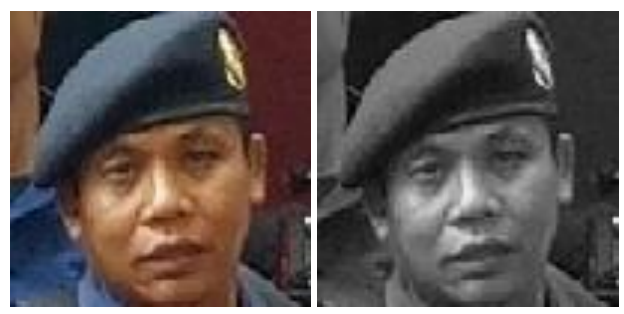

Fig. 6Image template which has already been greyish

After all has been processed to be greyscale or greyish the system will fit the greyscale prime image to the greyscale template image using library in OpenCV3. If it is done, the next step is showing all images on that application The color prime image and

greyscale prime image will be presented. Then the template image and greyscale template image will be shown in the final result of the image which has been detected with square mark. 


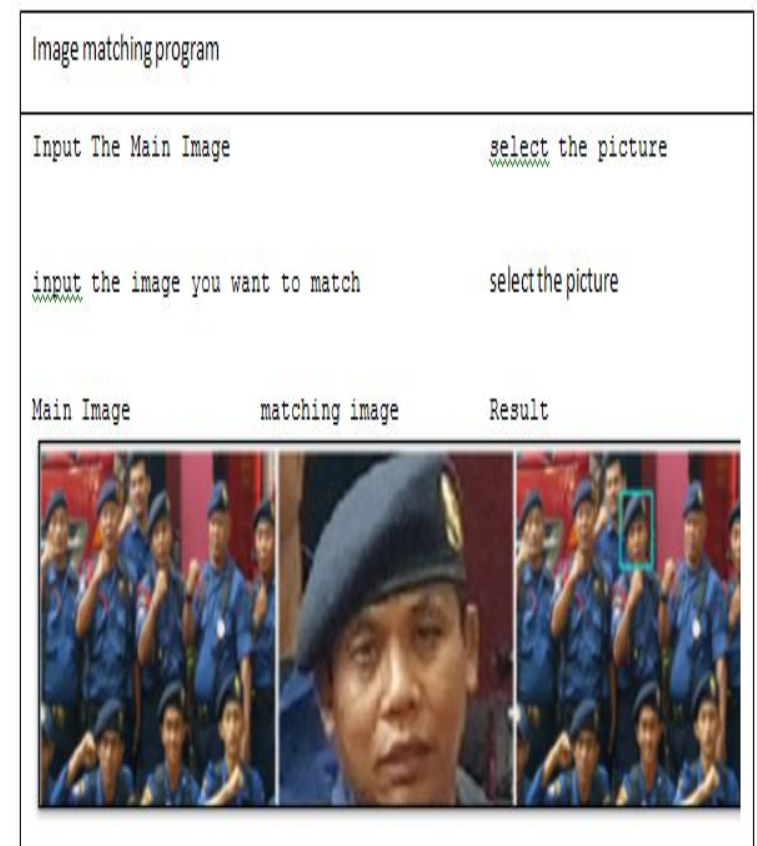

Fig. 7The result of detection

This is the table of application test using template matching method.

Table 3 The result of template matching testing

\begin{tabular}{|c|c|c|c|}
\hline $\begin{array}{l}\text { IMAGE } \\
\text { NAME }\end{array}$ & $\begin{array}{l}\text { IMAGE } \\
\text { TEMPLATE }\end{array}$ & $\begin{array}{l}\text { TEST IMAGE } \\
\text { NAME }\end{array}$ & TEST RESULT \\
\hline $\begin{array}{l}\text { FIGURE1.jp } \\
\mathrm{g}\end{array}$ & & $\begin{array}{c}\text { RESULT1.jp } \\
\mathrm{g}\end{array}$ & \\
\hline $\begin{array}{l}\text { FIGURE2.jp } \\
\mathrm{g}\end{array}$ & & $\begin{array}{c}\text { RESULT2.jp } \\
\mathrm{g}\end{array}$ & \\
\hline $\begin{array}{c}\text { FIGURE3.jp } \\
\mathrm{g}\end{array}$ & & $\begin{array}{c}\text { RESULT3.jp } \\
\mathrm{g}\end{array}$ & \\
\hline $\begin{array}{c}\text { FIGURE4.jp } \\
\mathrm{g}\end{array}$ & & $\begin{array}{c}\text { RESULT4.jp } \\
\mathrm{g}\end{array}$ & \\
\hline $\begin{array}{l}\text { FIGURE5.jp } \\
\mathrm{g}\end{array}$ & & $\begin{array}{c}\text { RESULT5.jp } \\
\mathrm{g}\end{array}$ & \\
\hline
\end{tabular}

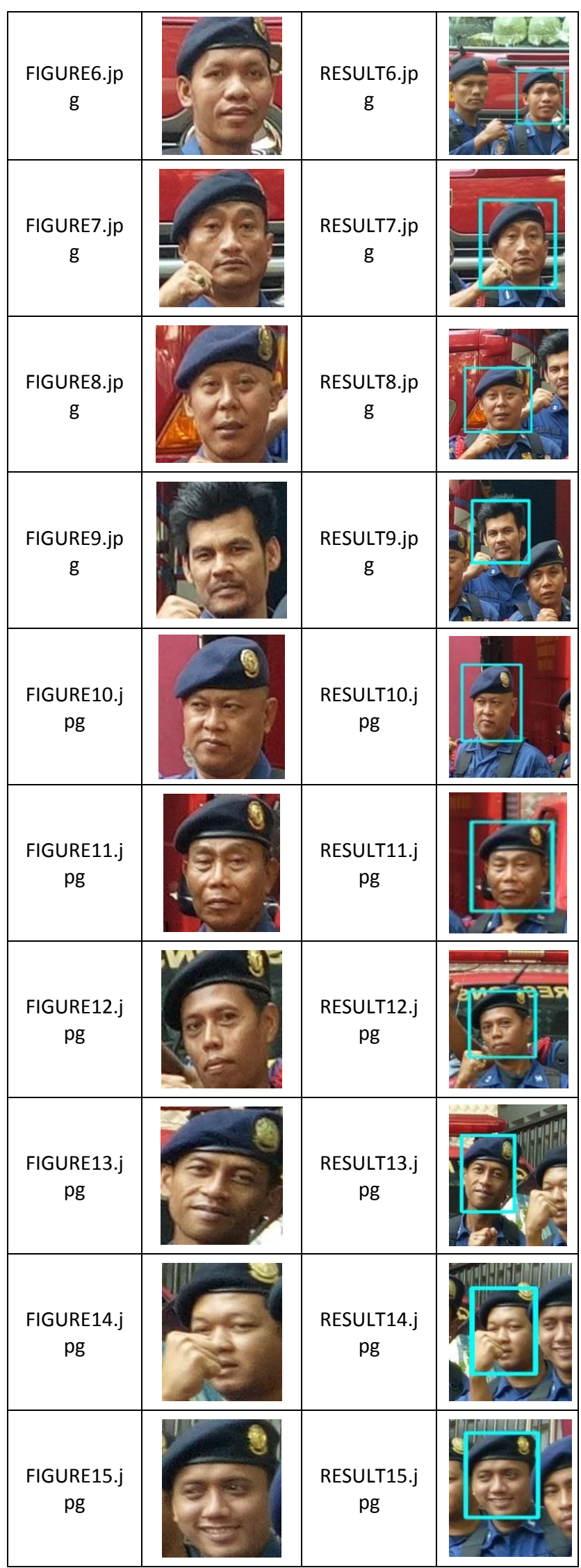




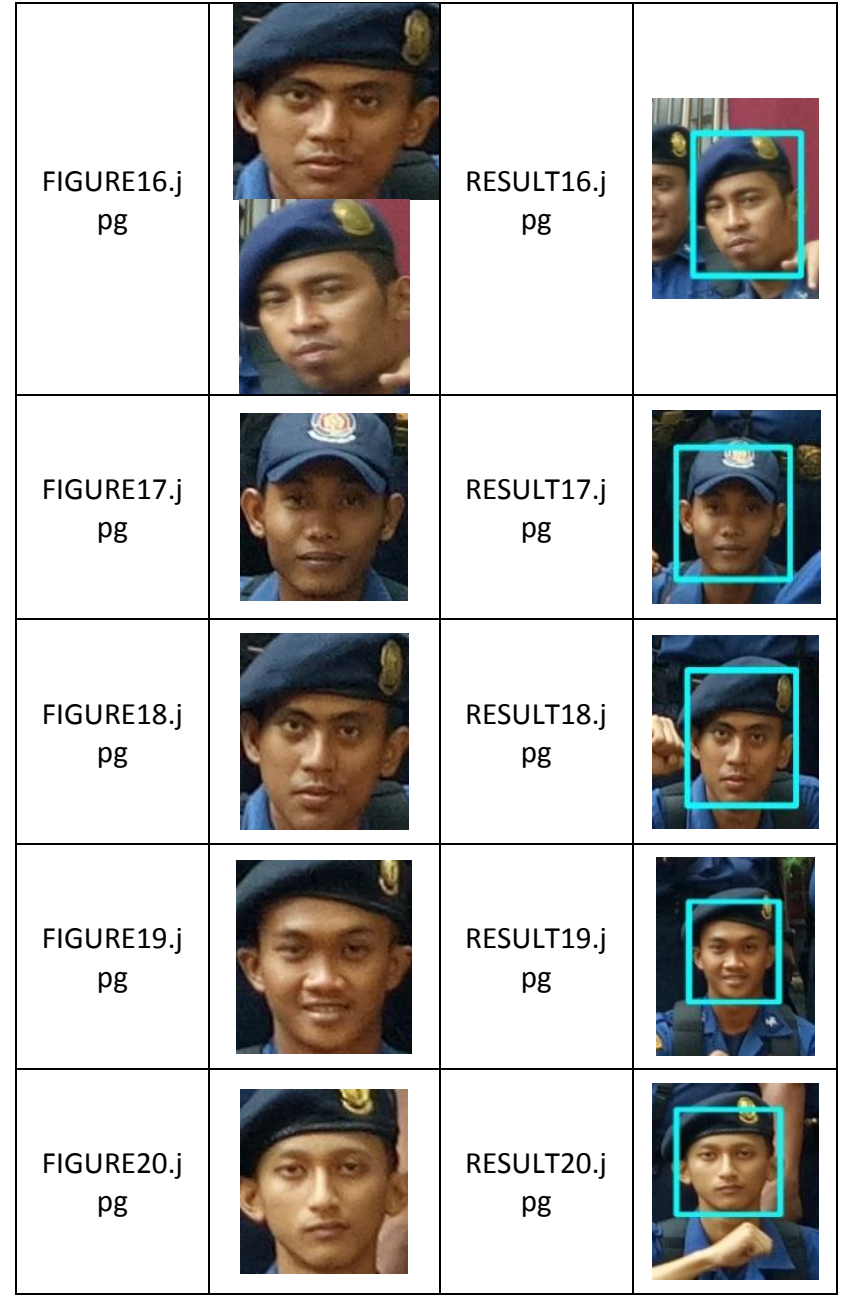

The result of test on the table shows that from 30 data of color image used as data basis, the application can detect the result of face template which the level of identification is $100 \%$, with 30 images. Thus the percentage of success of the color image face area detection can be counted using the formula below.

$$
\% \text { Gains }=\frac{\sum_{N} \tau}{\sum_{N} S} X 100 \%=\frac{30}{30} X 100 \%=100 \%
$$

is the result of detection which the level of identification is $100 \%$ andis a number of images.

By using 30 color images to test the performance of the application using template matching method it gains $100 \%$ success on face area detection.

\section{CONCLUSION}

The are some conclusions we gain from the research.

1. The result of research using template matching method can be used to detect face which has the same pixel. It is between the data template which is the result of crop and input data template. If the image is not detected it is absolutely not suitable to the prime image which is not detected.

2. The result of testing the application with 30 color images indicates that it is $100 \%$ and has high accuracy.

3. $100 \%$ results obtained from the detection of colored facial images are changed to grayscale or gray.
After that the photo template detects the original image by counting by using the matrix to determine the position of the face on the original image. To get a precise and accurate final result then the matrix calculation of $\mathrm{x}$ and $\mathrm{y}$ must be precise at position of template and determine level of tresholding equal to 0.9 to get accurate result. The conditions in question, the size, and position of the object image because the template matching method is very sensitive to differences in pixel values.

\section{ACKNOWLEDGMENTS}

Our thanks to the experts who have contributed towards development of the template.

\section{REFERENCES}

[1] Thiang, Andre Teguh Guntoro, Resmana Lim, Type of Vehicle Recognition Using Template Matching Method, Proc. of the International Conf. on Electrical, Electronics, Communication, and Information CECI'2001, March 78, Jakarta.

[2] Achmad Hidayatno, R. Rizal Isnanto, Dhody Kurniawan, Penentuan Wilayah Wajah Manusia Pada Citra Berwarna Berdasarkan Warna Kulit Dengan Metode Template Matching, Jurnal Teknologi Elektro, Vol 5 No 2, Juli 2006.

[3] Miftachul Arif Yunifa, Achmad Sabar, Sistem Pengenalan Wajah Menggunakan Metode Template Matching, International STMIK Asia Malang

[4] Bowo Leksono, Achmad Hidayatno, R.Rizal Isnanto,Aplikasi Metode Template Matching Untuk Klasifikasi Sidik Jari, TRANSMISI, 13 (1), 2011, 1-6

[5] Adhitya Whisnu, Penggunaan Metode Template Matching Untuk Identifikasi Kacacatan Pada PCB, Seminar Nasional Aplikasi Teknologi Informasi 2008 (SNATI 2008), Yogyakarta, 21 Juni 2008.

[6] Dani Rohpandi, R. Asep Sugiharto, Giri Aji Winara, Aplikasi Pengolahan Citra Ngalagena Manggunakan Matlab, Konferensi Nasional Sistem \& Informatika 2015,Bali, 9-10 Oktober 2015.

[7] Mulyadi H Handry, Thiang, Pengenalan Rambu Lalu Lintas Sederhana Dengan Menggunakan Metode Template Matching, Proceedings, Komputer dan Sistem Intelijen (KOMMIT 2002), Gunadarma, Jakarta.

[8] Setyo Nugroho, Agus Harjoko, Penerapan Jaringan Syaraf Tiruan Untuk Mendeteksi Posisi Wajah Manusia Pada Citra Digital, Seminar Nasional Aplikasi Teknologi Informasi 2005 (SNATI 2005), Yogyakarta, 18 Juni 2005.

[9] Rijal Yusron, R. Dian Arifianto, Deteksi Wajah Berbasis Segmentasi Model Warna Menggunakan Template Matching Pada Objek Bergerak, Seminar Nasional Aplikasi Teknologi Informasi 2008 (SNATI 2008), Yogyakarta, 21 Juni 2008.

[10] Hanif Dwiadi M, Sofia Naning Hertiana, Gelar Budiman,Pengenalan Bilangan Arab Menggunakan Template Matching, Telkom University.

[11] Y.M.Fouda ,A Robust Template Matching Algorithm Based on Reducing Dimensions, Journal of Signal and Information Processing, 2015, 6, 109-122 
[12] C. Saravanan, M. Surender,Algorithm for Face Matching Using Normalized Cross-Correlation, International Journal of Engineering and Advanced Technology (IJEAT) ISSN: 2249 - 8958, Volume-2, Issue-4, April 2013

[13] Kamarul Hawari Bin Ghazali, Jie Ma, Rui Xiao, An Innovative Face Detection based on Skin Color Segmentation, International Journal of Computer Applications (0975 - 8887), Volume 34- No.2, November 201

[14] Inseong Kim, Joon Hyung Shim, Jinkyu Yang,Face detection.

[15] Waqar Mohsin, Noman Ahmed, Chung-Tse Mar, Face Detection Project, Department of Electrical Engineering Stanford University.

[16] Scott Tan Yeh Ping, Chun Hui Weng, Boonping Lau, Face Detection Trought Template Matching And Color
Segmentation, Department of Electrical Engineering Stanford University.

[17] Kamarul Diedrick Marius, Sumita Pennathur, Klint Rose, Face Detection Using Color Thresholding, and Eigenimage Template Matching.

[18] Smita Tripathi, Varsha Sharma, Sanjeev Sharma,Face detection Using Combined Skin Color Detector and Template Matching Method. International Journal of Computer Applications (0975 - 8887), Volume 26No.7, July 2011.

[19] S.Vijayarani, A.Sakila, Template Matching Technique For Searching Words In Document Images, International Journal on Cybernetics \& Informatics (IJCI) Vol. 4, No. 6, December 2015.

[20] Dewi Agushinta R,Pengenalan Wajah Sebagai Bagian Dari Sistem Pengenalan Biometrik, Proceedings, Komputer dan Sistem Intelijen (KOMMIT 2004), Gunadarma, Jakarta. 